Огляди літератури, оригінальні дослідження, погляд на проблему, ювілеї

УДК 612.017.2-02:612.766.2-06:616-001.8-092.19]-092.9

DOI 10.11603/1811-2471.2019.v0.i1.10048

\title{
МЕХАНІЗМИ АДАПТАЦІї ДО ІММОБІЛІЗАЦІЙНОГО СТРЕСУ В НИЗЬКОСТІЙКИХ ДО ГІПОКСІї ЩУРІВ РІЗНОї СТАТІ
}

\author{
๑О. В. Денефіль, Ю. М. Ординський, М. О. Рябоконь, С. С. Рябоконь \\ ДВНЗ «Тернопільський державний медичний університет імені І. Я. Горбачевського МОз України»
}

РЕЗЮмЕ. Гіпоксія $є$ одним із провідних факторів розвитку багатьох хвороб. Гіподинамія також призводить до розвитку захворювань серцево-судинної системи. Визначення механізмів, які забезпечують пристосування до малорухомого способу життя в осіб із різною реактивністю, може сприяти розробці індивідуальних методів профілактики і корекції виявлених порушень.

Мета - визначити показники антиоксидантної системи та стан автономної нервової системи у щурів різної статі з низькою стійкістю до гіпоксії при іммобілізаційному стресі.

Матеріал і методи. Стрес моделювали 4 рази годинною іммобілізацією щурів спинкою донизу з інтервалом 24 години. У серці визначали активність супероксиддисмутази (СОД), каталази, концентрацію відновленого глутатіону, активність глутатіонпероксидази (ГП), глутатіонредуктази (ГР), у крові - пероксидазну активність. Тваринам проводили кардіоінтервалографію.

Результати. В інтактних щурів-самців порівняно із самицями спостерігається більша активність антиоксидантів. При стресі відмічено зростання СОД і каталази, зменшення пероксидазної активності крові у тварин незалежно від статі. Виявлені зміни активності ферментів були достовірно більшими у самиць. При стресі відмічено зростання відновленого глутатіону, зменшення ГП і ГР, у самиць - зниження відновленого глутатіону, збільшення ГП і ГР. При проведенні кардіоінтервалографії виявлено, що в інтактних самців більші адренергічні впливи на серце. При стресі зменшуються симпатичні впливи у всіх щурів, у самців зменшуються регуляторні впливи на серце, а в самиць збільшується виділення адреналіну гуморальними каналами.

Висновки. В інтактних низькостійких до гіпоксії щурів-самців порівняно із самицями більша активність антиоксидантів, що може бути зумовлено вищим рівнем обмінних процесів у серці. Інтервальна іммобілізація низькостійких до гіпоксії щурів призводить до активації антиоксидантів, що більше виражено у самиць. В інтактних самців переважають адренергічні впливи на серце. Інтервальна іммобілізація низькостійких до гіпоксії щурів призводить до зниження тонусу симпатичного відділу автономної нервової системи, що має кисеньзберігаючий ефект, спричинює зниження регуляторних механізмів на серце тільки у самців.

КЛючовІ слОВА: іммобілізаційний стрес; щури; резистентність до гіпоксії; антиоксидантна система; кардіоінтервалографія.

Вступ. Реакція на стрес може залежати від віку, статі, особливостей автономної регуляції, стану центральної нервової, ендокринної системи, вищої нервової діяльності тощо [9]. Стреси $\epsilon$ невід'ємними супутниками нашого життя [10]. Вони можуть приводити як до адаптації, так і до її зриву, розвитку різноманітних захворювань [11]. Гіподинамія, нестача часу для виконання роботи, безробіття призводять до розвитку дистресу. При надмірному стресі страждає робота внутрішніх органів, зокрема серцево-судинної системи [8]. У популяціях $є$ особини з різною стійкістю до стресу, гіпоксії тощо. До механізмів, які забезпечують підвищену стійкість до гіпоксії, належать антиоксидантна система та підвищені холінергічні впливи на серце [9]. Визначення адаптаційних механізмів, які забезпечують пристосування в осіб із низькою резистентністю до гіпоксії, може сприяти розробці індивідуальних методів профілактики та корекції при розвитку патологічних процесів.

Мета - визначити показники антиоксидантної системи та стан автономної нервової системи у щурів різної статі з низькою стійкістю до гіпоксії при іммобілізаційному стресі.
Матеріал і методи дослідження. Досліди виконано на 72 безпородних низькостійких до гіпоксії щурах віком 5,5-6 місяців. Тварин поділено на три групи - контрольну та дві дослідних (які зазнали різних режимів іммобілізаційного стресу). У кожній із груп було по 12 самців і 12 самиць. Виділення із загальної когорти тварин особин із різною стійкістю до гіпоксії проводили за методикою В. Я. Березовського (1978) [1]. Стрес моделювали шляхом чотириразової одногодинної іммобілізації щурів спинкою донизу з інтервалом у 24 години між окремими стресовими епізодами [3].

Усі експерименти проводили в першій половині дня в спеціально відведеному приміщенні при температурі $18-22^{\circ} \mathrm{C}$, відносній вологості 40$60 \%$ і освітленості 250 лк. Досліди виконано з дотриманням норм Європейської конвенції про захист хребетних тварин, що використовуються для дослідних та інших наукових цілей (Страсбург, 18.03.1986 р.), ухвали Першого національного конгресу з біоетики (Київ, 2001) і наказу МО3 України № 690 від 23.09.2009 р.

Евтаназію щурів проводили шляхом тотального кровопускання з серця після попереднього тіо- 
Огляди літератури, оригінальні дослідження, погляд на проблему, ювілеї

пентало-натрієвого наркозу (60 мг·к $\Gamma^{1}$ маси тіла тварини внутрішньочеревно). Для подальшого експериментального дослідження у гомогенаті серця визначали активність супероксиддисмутази (СОД) [7], каталази [4, 6], пероксидазну активність крові (ПАК) [5, 6], відновлений глутатіон (GSH) [12], глутатіонпероксидазу (ГП), глутатіонредуктазу (ГР) [2]. Для дослідження варіабельності серцевого ритму було використано метод варіаційної кардіоінтервалометрії. Для реєстрації використовували пристрій «Кардіолаб» (Харків, Україна). Проводили запис 1000 послідовно розташованих кардіоінтервалів R-R.
Статистичну обробку цифрових даних виконано за допомогою програмного забезпечення «Excel» ("Microsoft», CШA) та "STATISTICA» 6.0 ("Statsoft», США). Достовірність різниці значень між незалежними кількісними величинами визначали при нормальному розподілі за критерієм Стьюдента, в інших випадках - за допомогою непараметричних методів.

Результати й обговорення. 3 метою дослідження механізмів захисту при окисному стресі досліджували зміни показників антиоксидантної системи (табл. 1).

Таблиця 1. Зміни показників антиоксидантного стану, викликані стресом, у серці та крові самців і самиць щурів, $M \pm m(n=12)$

\begin{tabular}{|l|c|c|c|}
\hline \multirow{2}{*}{ Група } & \multicolumn{3}{|c|}{ Показник } \\
\cline { 2 - 4 } & $\begin{array}{c}\text { супероксиддисмутаза, } \\
\text { м. од. } \cdot \text { мг }^{-1}\end{array}$ & $\begin{array}{c}\text { каталаза, } \\
\text { мкат/кг }\end{array}$ & $\begin{array}{c}\text { пероксидазна активність крові, } \\
\text { мг/л }\end{array}$ \\
\hline \multicolumn{3}{|c|}{ Самці } \\
\hline Контроль & $0,71 \pm 0,01$ & $1,26 \pm 0,06$ & $322,48 \pm 3,38$ \\
\hline Стрес & $1,35 \pm 0,02^{*}$ & $1,48 \pm 0,08^{*}$ & $151,33 \pm 0,91^{*}$ \\
\hline \multicolumn{4}{|c|}{ Самиці } \\
\hline Контроль & $0,65 \pm 0,01 \#$ & $1,09 \pm 0,01 \#$ & $270,38 \pm 3,76 \#$ \\
\hline Стрес & $2,39 \pm 0,30^{*}, \#$ & $4,73 \pm 0,22^{*}, \#$ & $159,24 \pm 5,44^{*}$ \\
\hline
\end{tabular}

Примітка: * - показники достовірні, порівняно з контролем; \# - показники достовірні, порівняно з самцями.

При стресі у самців активність СОД збільшилася на $89,42 \%(p<0,001)$, аналогічно змінилася й активність каталази - зросла на $17,43 \%(p<0,05)$, ПАК зменшилася на 53,07 \% (p<0,001). При стресі у самиць зросла активність СОД в 3,70 раза $(p<0,001)$, активність каталази в 4,34 раза $(p<0,001)$. ПАК зменшилася на $41,11 \%(p<0,001)$.

В інтактних самців порівняно з самицями були вищі активності СОД на 9,32 \% ( $<<0,001)$, каталази - на 13,72 \% ( $<<0,01)$, ПАК - на $16,15 \%$ $(p<0,001)$. При порівнянні результатів при стресі у самиць порівняно із самцями виявлено більшу активність СОД (на $77,08 \%, \mathrm{p}<0,001)$ та каталази (у 3,19 раза, $p<0,001)$.

Антиоксидантні системи протидіють прооксидантним системам, які генерують активні форми кисню (АФК). Первинні АФК інактивуються супероксиддисмутазою (СОД), каталазою та пероксидазами. СОД каталізує реакцію дисмутації двох молекул супероксиданіону з утворенням перекису водню та кисню. $\mathrm{H}_{2} \mathrm{O}_{2} \in$ субстратом для каталази та пероксидази, які знешкоджують його $з$ утворенням води та кисню. Пероксидаза також каталізує редукцію гідроперекисів жирних кислот. Спорідненість ії до перекису водню вища, ніж у каталази, і вона більше знешкоджує $\mathrm{H}_{2} \mathrm{O}_{2}$ за низьких концентрацій, а при окиснювальному стресі ключова роль в захисті клітин від $\mathrm{H}_{2} \mathrm{O}_{2}$ належить каталазі [12]. У наших дослідах у контролі інтенсивність метаболічних процесів у тканинах вища у самців. При стресі у самців і самиць відбувається інтенсифікація процесів вільнорадикального окиснення ліпідів і швидке знешкодження цих продуктів. На це вказують зростання СОД, каталази і зниження ПАК. У самиць при стресі відмічено більшу активацію антиоксидантів, що, можливо, пов'язано із інтенсивнішим утворенням АФК у результаті більшої чутливості до іммобілізаційного стресу.

При вивченні показників системи глутатіону виявлено таке (табл. 2). При стресі у самців зросли значення GSH на 49,30\% ( $<<0,001)$, знизилася активність ГП (на 17,62 \%, р<0,001) і ГР (на 56,37\%, $p<0,001)$.

При стресі у самиць зменшилося значення GSH на $72,11 \%(p<0,001)$, активність ГП зросла на $70,85 \%(p<0,001)$, ГР - на 24,31\% ( $<<0,001)$.

При порівнянні результатів самців і самиць виявлено таке. У контролі у самців були більші показники ГР на 54,36 \% ( $<<0,001)$. При стресі у самців були більші показники GSH на $80,75 \%$ $(p<0,001)$, значення ГП були менші в 2,1 раза $(p<0,001)$, гР - на 30,06\% $(p<0,001)$.

Суттєву роль у підтриманні редокс-потенціалу клітин крові, який визначає ефективність їх функціонування, відіграють SH-групи протеїнів i відновлений глутатіон. Вони виконують роль акцепторів гідроксильного радикала (НО•) і синглетного кисню, знижуючи деструктивну і цитотоксичну дію активних форм кисню. Оскільки у 
Огляди літератури, оригінальні дослідження, погляд на проблему, ювілеї

Таблиця 2. Зміни показників системи глутатіону, викликані стресом у серці низькостійких до гіпоксії тварин різної статі, $\mathrm{M} \pm \mathrm{m}(\mathrm{n}=12)$

\begin{tabular}{|l|c|c|c|}
\hline \multirow{2}{*}{ Група } & \multicolumn{3}{|c|}{ Показник } \\
\cline { 2 - 4 } & $\begin{array}{c}\text { відновлений глутатіон, } \\
\text { мкмоль/г }\end{array}$ & $\begin{array}{c}\text { глутатіон-пероксидаза, } \\
\text { ммоль/хв·Кг }\end{array}$ & $\begin{array}{c}\text { глутатіон-редуктаза, } \\
\text { ммоль/хв·кг }\end{array}$ \\
\hline \multicolumn{3}{|c|}{ Самці } \\
\hline Контроль & $625,73 \pm 25,31$ & $0,226 \pm 0,004$ & $0,616 \pm 0,004$ \\
\hline Стрес & $934,21 \pm 20,39^{*}$ & $0,186 \pm 0,009^{*}$ & $0,269 \pm 0,004^{*}$ \\
\hline \multicolumn{4}{|c|}{ Самиці } \\
\hline Контроль & $644,74 \pm 12,05$ & $0,228 \pm 0,002$ & $0,349 \pm 0,007^{*}, \#$ \\
\hline Стрес & $179,82 \pm 6,87^{*}, \#$ & $0,390 \pm 0,026^{*}, \#$ & \\
\hline
\end{tabular}

Примітка: * - показники достовірні, порівняно з контролем; \# - показники достовірні, порівняно із самцями відповідної групи.

самців відмічено зростання концентрації відновленого глутатіону, а у самиць - його зниження, то можна думати, що такі протилежно направлені зміни у роботі системи глутатіону самців і самиць вказують на різні механізми антиоксидантного захисту.

При дослідженні показників кардіоінтервалографії (табл. 3) виявлено, що у самців при стресі порівняно з контролем зменшилися значення амплітуди моди (AMo) на $31,67 \%(p<0,001)$ та індексу напруження (IH) на $38,90 \%(p<0,05)$. У самиць при стресі відмічено такі зміни показників кардіоінтервалографії: зменшилася мода (Мо) на $9,54 \%$ ( $p<0,01)$, АМо - на 24,54 \% ( $<<0,05)$, збільшилася частота серцевих скорочень (ЧСС) на $10,33 \%(p<0,01)$.

Таблиця 3. Зміни показників кардіоінтервалографії, викликані стресом, у низькостійких до гіпоксії тварин різної статі $(\mathrm{M} \pm \mathrm{m})$

\begin{tabular}{|c|c|c|c|c|}
\hline \multirow{2}{*}{ Група } & \multicolumn{4}{|c|}{ Показник } \\
\hline & Mo, C & AMo, \% & $\mathrm{BP}, \times 10^{-2}, \mathrm{C}$ & $\mathrm{IH}, \mathrm{x} 10^{2}$, ум. од. \\
\hline \multicolumn{5}{|c|}{ Самці } \\
\hline Контроль (n=12) & $0,129 \pm 0,002$ & $48,17 \pm 2,27$ & $0,80 \pm 0,03$ & $453,64 \pm 54,74$ \\
\hline Стрес (n=9) & $0,130 \pm 0,002$ & $32,91 \pm 2,77^{*}$ & $0,60 \pm 0,10$ & $277,18 \pm 44,37^{*}$ \\
\hline \multicolumn{5}{|c|}{ Самиці } \\
\hline Контроль $(n=10)$ & $0,147 \pm 0,003^{\#}$ & $45,27 \pm 2,80$ & $0,53 \pm 0,06$ & $341,88 \pm 53,27$ \\
\hline Стрес $(n=10)$ & $0,133 \pm 0,003^{*}$ & $34,16 \pm 3,53^{*}$ & $0,55 \pm 0,07$ & $311,19 \pm 61,21$ \\
\hline
\end{tabular}

Примітка: * - показники достовірні, порівняно з контролем; \#- показники достовірні, порівняно із самцями відповідної групи.

При порівнянні показників між самцями і самицями виявлено у контрольних самців менші значення Мо (на 13,94\%, р<0,001). При стресі змін показників у тварин різної статі не було.

Отже, у контролі у самиць порівняно із самцями менші адренергічні впливи на серце. При стресі у тварин, незалежно від статі, зменшуються адренергічні впливи на серце нервовими терміналями. Очевидно, це сприяє меншому споживанню кисню серцем в умовах стресу, спричинює зменшення оксидативних процесів. У самців дане пригнічення виділення норадреналіну спричинює зменшення регуляторних процесів на серце, що може мати як пристосувальний ефект, так і призводити до розвитку аритмій. У самиць регуляторні механізми не порушуються, оскільки надниркові залози виділяють більше адреналіну. Можна думати, що у самиць спрацьовують адекватні регуляторні механізми у відповідь на стрес, тобто для них дана модель адаптації до стресу $є$ адаптивною.
Висновки. 1. В інтактних низькостійких до гіпоксії щурів-самців порівняно із самицями більша активність антиоксидантів, що може бути зумовлено вищим рівнем обмінних процесів у серці. Інтервальна іммобілізація низькостійких до гіпоксії щурів призводить до активації антиоксидантів, що більше виражено у самиць.

2. В інтактних самців переважають адренергічні впливи на серце. Інтервальна іммобілізація низькостійких до гіпоксії щурів призводить до зниження тонусу симпатичного відділу автономної нервової системи, що має кисеньзберігаючий ефект, спричинює зниження регуляторних механізмів на серце тільки у самців.

Перспективи подальших досліджень. Вивчити механізми забезпечення підвищеної стійкості до гіпоксії у тварин різної статі, які зазнали іммобілізаційного стресу. 
Огляди літератури, оригінальні дослідження, погляд на проблему, ювілеї

\section{ЛІТЕРАТУРА}

1. Березовский В. А. Гипоксия и индивидуальные особенности реактивности / В. А. Березовский. - К. : Наукова думка, 1978. - 216 с.

2. Круглікова Г. О. Глутатіонпероксидазна та глутатіонредуктазна активність печінки щурів після введення селеніту натрію / Г. О. Круглікова, І. М. Штутман // Укр. біохім. журн. - 1976. - № 2. - С. 227-233.

3. Кулинский В. И. Две адаптационные стратегии в неблагоприятных условиях: резистентная и толерантная. Роль гормонов и рецепторов / В. И. Кулинский, И. А. Ольховский // Успехи современной биологии. 1992. - Т. 112. - С. 697-711.

4. Метод определения активности каталазы / М. А. Королюк, Л. И. Иванова, И. Г. Майорова, В. Е. Токарев // Лабораторное дело. - 1988. - № 1. - С. 16-19.

5. Попов Т. Метод определения пероксидазной активности крови / Т. Попов, Л. Нейковская // Гигиена и санитария. - 1971. - № 10. - С. 89-93.

6. Ракитянський В. М. Пероксидазна та каталазна активність крові у голштинської худоби за дії гідрогумату і мікроелементів // В. М. Ракитянський, В. Г. Єфімов / Науковий вісник ЛНУВМБТ імені С. 3. Ґжицького.-2010.Т. 12, № 2 (44). - Ч. 2. - С. 250-255.

\section{REFERENCES}

1. Berezovskiy, V.A. (1978). Gipoksiya i individualnye osobennostireaktivnosti[Hypoxia and individual peculiarities of reactivity]. Kyiv: Naukova dumka [in Russian].

2. Kruhlikova, H.O. \& Shtutman, I.M. (1976). Hlutationperoksydazna ta hlutationreduktazna aktyvnist pechinky shchuriv pislia vvedennia selenitu natriiu [Glutathionperoxidase and glutathionreductase activity of rats liver after the introduction of selenite of sodium]. Ukrainskyi biokhimichnyi zhurnal - Ukrainian Biochemical Journal, 2, 227-233 [in Ukrainian].

3. Kulynskyy, V.I. \& Olkhovskyy, I.A. (1992). Dve adaptatsionnie strategii $v$ neblagopriyatnykh usloviyakh: rezistentnaya i tolerantnaya. Rol gormonov i retseptorov [Two adaptation strategies in adverse conditions: resistant and tolerant. The role of hormones and receptors]. Uspekhi sovremennoy biologii - Advances of Modern Biology, 112, 697-711 [in Russian].

4. Koroliuk, M.A., Ivanova. L.I., Mayorova, I.G., \& Tokarev, V.E. (1988). Metod opredeleniya aktivnosti katalazy [Method for determination of catalase activity]. Laboratornoye delo - Laboratory Work, 1, 16-19 [in Russian].

5. Popov, T. \& Neikovska, L. (1971). Metod opredeleniya peroksidaznoy aktivnosti krovi [Method for determination of blood peroxidase activity] Gigiena i sanitariya - Hygiene and Sanitation, 10, 89-93 [in Russian].

6. Rakytianskyi, V.M., \& Yefimov, V.H. (2010). Peroksydazna ta katalazna aktyvnist krovi u holshtynskoi khudoby za dii hidrohumatu i mikroelementiv [Peroxidase and catalase activity of blood in Holstein cattle for the effects of
7. Чевари С. Роль супероксиддисмутазы в окислительных процессах клетки и метод определения ее в биологических материалах / С. Чевари, И. Чаба, Й. Сокей // Лаб. дело. - 1985. - № 11. - С. 678-681.

8. Angina and mental stress-induced myocardial ischemia / P. Pimple, A. J. Shah, C. Rooks [et al.] // J. Psychosom. Res. - 2015. - Vol. 78 (5). - P. 433-437.

9. Crea F. Sex differences in mechanisms, presentation and management of ischaemic heart disease / F. Crea, I. Battipaglia, F. Andreotti // Atherosclerosis. - 2015. Vol. 241 (1). - P. 157-168.

10. Expressive flexibility in combat veterans with posttraumatic stress disorder and depression / R. Rodin, G. A. Bonanno, N. Rahman [et al.] // J. Affect. Disord. - 2016. Vol. 207. - P. 236-241.

11. Kötter T. Resource-oriented coaching for reduction of examination-related stress in medical students: an exploratory randomized controlled trial / T. Kötter, F. Niebuhr // Adv. Med. Educ. Pract. - 2016. - Vol. 7. - P. 497-504.

12. Moffat J. A. Investigations into the role of sulfhydryl groups in the mechanism of action of the nitrates / J. A. Moffat, P. W. Armstrong, G. S. Marks // Canadian Journal of Physiology and Pharmacology. - 1982. - Vol. 60, No. 10. P. 1261-1266.

hydrogum and microelements]. Naukovyi visnyk LNUVMBT imeni S.Z. Hzhytskoho - Scientific Herald of LNUWMBT named after S.Z. Hzhytskyi, 12, 250-255 [in Ukrainian].

7. Chevary, S., Chaba, Y., \& Sokey, Y. (1985). Rol superoksiddysmutazy $v$ okislitelnykh protsessakh kletki i metod opredeleniya ee $v$ biologicheskikh materialakh [The role of superoxide dismutase in the oxidative processes of the cell and the method for its determination in biological materials]. Laboratornoye delo - Laboratory Work, 11, 678681 [in Russian].

8. Pimple, P., Shah, A.J., Rooks, C., Bremner, J.D., Nye, J., Ibeanu, I., Raggi P., \& Vaccarino, V. (2015). Angina and mental stress-induced myocardial ischemia. J. Psychosom. Res. 78 (5), 433-437.

9. Crea, F., Battipaglia, I., \& Andreotti, F. (2015). Sex differences in mechanisms, presentation and management of ischaemic heart disease. Atherosclerosis, 241 (1), 157-168.

10. Rodin, R., Bonanno, G.A., Rahman, N., Kouri, N.A., Bryant, R.A., Marmar, C.R., \& Brown, A.D. (2016). Expressive flexibility in combat veterans with posttraumatic stress disorder and depression. J. Affect. Disord., 207, 236-241.

11. Kötter, T. \& Niebuhr, F. (2016). Resource-oriented coaching for reduction of examination-related stress in medical students: an exploratory randomized controlled trial. Adv. Med. Educ. Pract., 7, 497-504.

12. Moffat, J.A., Armstrong, P.W., \& Marks, G.S. (1982). Investigations into the role of sulfhydryl groups in the mechanism of action of the nitrates. Canadian Journal of Physiology and Pharmacology, 60 (10), 1261-1266. 


\title{
๑О. В. Денефиль, Ю. Н. Ордынский, М. А. Рябоконь, С. С. Рябоконь
}

ГВУз «Тернопольский государственный медицинский университет имени И. Я. Горбачевского МОз Украины»

PЕЗЮМЕ. Гипоксия является одним из ведущих факторов развития многих заболеваний. Гиподинамия также приводит к развитию заболеваний сердечно-сосудистой системы. Определение механизмов, обеспечивающих приспособление к малоподвижному образу жизни у лиц с разной реактивностью, может способствовать разработке индивидуальных методов профилактики и коррекции выявленных нарушений.

Цель - определить показатели антиоксидантной системы и состояние вегетативной нервной системы у крыс разного пола с низкой устойчивостью к гипоксии при иммобилизационном стрессе.

Материал и методы. Стресс моделировали 4 раза путем часовой иммобилизации крыс спинкой вниз с интервалом 24 часа. В сердце определяли активность супероксиддисмутазы (СОД), каталазы, концентрацию восстановленного глутатиона, активность глутатионпероксидазы (ГП), глутатионредуктазы (ГР), в крови - пероксидазную активность. Животным проводили кардиоинтервалографию.

Результаты. У интактных крыс-самцов по сравнению с самками наблюдается большая активность антиоксидантов. При стрессе отмечен рост СОД и каталазы, уменьшение пероксидазной активности крови у животных независимо от пола. Обнаруженные изменения активности ферментов были достоверно большими у самок. При стрессе отмечен рост восстановленного глутатиона, уменьшение ГП и ГР, у самок - снижение восстановленного глутатиона, увеличение ГП и ГР. При проведении кардиоинтервалографии обнаружено, что у интактных самцов большие адренергические влияния на сердце. При стрессе уменьшаются симпатические влияния у всех крыс, у самцов уменьшаются регуляторные влияния на сердце, а у самок увеличивается выделение адреналина гуморальными каналами.

Выводы. У интактных низкоустойчивых к гипоксии крыс-самцов по сравнению с самками большая активность антиоксидантов, что может быть обусловлено более высоким уровнем обменных процессов в сердце. Интервальная иммобилизация низкоустойчивых к гипоксии крыс приводит к активации антиоксидантов, что больше выражено у самок. В интактных самцов преобладают адренергические влияния на сердце. Интервальная иммобилизация низкоустойчивых к гипоксии крыс приводит к снижению тонуса симпатического отдела вегетативной нервной системы, имеющей кислородосохраняющий эффект, вызывает снижение регуляторных механизмов на сердце только у самцов.

КЛЮЧЕВЫЕ СЛОВА: иммобилизационный стресс; крысы; резистентность к гипоксии; антиоксидантная система; кардиоинтервалография.

\section{MECHANISMS OF IMMOBILIZATION STRESS ADAPTATION IN LOW-RESISTANT TO HYPOXIA RATS OF DIFFERENT GENDER}

\author{
@O. V. Denefil, Yu. M. Ordynskyi, M. O. Riabokon, S. S. Ryabokon \\ I. Horbachevsky Ternopil State Medical University
}

SUMMARY. Hypoxia is one of the leading factors in development of many diseases. Hypodynamia also leads to development of diseases of cardiovascular system. Identification of mechanisms that provide adaptation to sedentary lifestyle in people with different reactivity can contribute to development of individual methods of prevention and correction of identified violations.

The aim of the study - to determine parameters of the antioxidant system and condition of the autonomous nervous system in rats of different gender with a low-resistance to hypoxia immobilization stress.

Material and Methods. Stress was modeled 4 times by an hour-long immobilization of rats back down with an interval each 24 hours. In the heart, the activity of superoxide dismutase (SOD), catalase, the concentration of reduced glutathione, activity of glutathione peroxidase (GP), glutathione reductase (GR), and peroxidase activity in blood were determined. Animals underwent cardiointervalography.

Results. In intact male rats, compared with females, there was higher activity of antioxidants. Under stress we noted the growth of SOD and catalase, decreased peroxidase activity of blood in animals, regardless of sex. Detected changes of activity of enzymes were significantly higher in females. Under stress we noted the growth of reduced glutathione, decreased GP and $\mathrm{GH}$, and in females - reduction of reduced glutathione, increase in GP and GR. In cardiointervalography study was found that in intact males, higher adrenergic effects on the heart. Under stress decreased sympathetic effects in all rats, in males reduce regulatory effects on the heart, and in females, the allocation of adrenaline is increased by humoral channels.

Conclusions. In intact low-resistance to hypoxia male rats, compared with females, higher antioxidant activity, which may be due to a higher level of metabolic processes in the heart. Interval immobilization of low-resistance to hypoxia rats leads to activation of antioxidants, which is more pronounced in females. In intact males adrenergic effects on the heart prevail. Interval immobilization of low-resistance to hypoxia rats leads to decrease tone of the sympathetic portion of the autonomic nervous system, which has an oxygen-retaining effect, causes the reduction of regulatory mechanisms on the heart only in males.

KEY WORDS: immobilization stress; rats; resistance to hypoxia; antioxidant system; cardiointervalography.

Отримано 11.02.2019 